The Catholic University of America, Columbus School of Law

CUA Law Scholarship Repository

1981

Artificial Insemination Redivivus: Permutations Within a

Penumbra

George P. Smith II

The Catholic University of America, Columbus School of Law

Follow this and additional works at: https://scholarship.law.edu/scholar

Part of the Family Law Commons

Recommended Citation

George P. Smith II, Artificial Insemination Redivivus: Permutations Within a Penumbra, 2 J. LEGAL MED. 113 (1981).

This Article is brought to you for free and open access by the Faculty Scholarship at CUA Law Scholarship Repository. It has been accepted for inclusion in Scholarly Articles and Other Contributions by an authorized administrator of CUA Law Scholarship Repository. For more information, please contact edinger@law.edu. 


\section{ARTIFICIAL INSEMINATION REDIVIVUS}

\section{Permutations Within A Penumbra}

George P. Smith, II, J.D., LL.M.*

\section{INTRODUCTION}

Judicial and legislative action are needed in order to chart a course of stability for decision-making in the field of artificial insemination. Because of the lethargy and benign neglect of the medical profession in policing itself in this arena, the courts will be forced to impose new and higher standards of care and responsibility, thereby tightening the laws of malpractice. Additional clarifying legislation will also have to be enacted creating a presumption at law of legitimacy for the issue born of consensual AID and thereby establishing both the legal rights and duties of the consenting husband. Donor liability must be scrupulously avoided. In cases where, for medical reasons, the identity of a donor is required, an in camera study of the matter should be conducted by a court and, where appropriate, a geneticist. Public disclosure of the donor's identity should always be avoided. When errors are caused due to carelessness in the genetic screening of a donor by a physician, the physician, not the donor, should be held liable.

Slowly, almost imperceptibly at times, the socio-legal mysteries of artificial insemination are being resolved. Yet, as these old

* Professor of Law, The Catholic University of America, Washington, D.C.; Distinguished Visiting Scholar, Kennedy Institute of Ethics, Georgetown University. Address reprint requests to Professor Smith at the Catholic University Columbus School of Law, Washing-
ton, D.C. 20064 . 
mysteries give way to solution, others evolve into permutations within the penumbric haze of the subject area itself. An analysis of two recent judicial determinations will serve as paradigms that focus upon the clear thrust of dynamic tensions in the decisionmaking process by the courts and yet, at the same time, point up the vast area of indecision still besetting the field. ${ }^{1}$ Before approaching an exegesis of these two cases, however, it is important to note briefly the background of the central problems that arise.

\section{OVERVIEW}

Usually in dealing with heterologous artificial insemination cases (AID), the donor is unknown. The quintessential issues here involve whether the putative father (i.e., the husband of the artificially inseminated mother) becomes the real father of the artificially conceived child and whether the wife has committed adultery by participating in such an act with or without her husband's consent.

As early as 1948, the New York Supreme Court recognized that a woman artificially inseminated by a third party donor, with her husband's consent, gave birth to a legitimate child. The woman's husband was "entitled to the same rights as that acquired by a foster parent who has formally adopted a child, if not the same rights as those to which a natural parent under the circumstances would be entitled."'2

In 1963, with the case of Gursky v. Gursky, ${ }^{3}$ however, a New York trial court held that even though a husband consents to his wife's use of AID, the child is nonetheless, illegitimate. A considerably more enlightened and contemporary California Supreme Court in People v. Sorensen ${ }^{4}$ rejected the Gursky thesis in 1968 and

\footnotetext{
${ }^{1}$ Fitzgerald v. Rueckl, No. 11433 (scheduled for argument before the Nevada Supreme Court, September 15, 1981, at 8:15 a.m.) and C.M. v. C.C., 152 N.J. Super. 160, 377 A.2d 821 (1977). See also Smith, A Close Encounter of the First Kind: Artificial Insemination and an Enlightened Judiciary, 17 J. FAM. L. 41 (1978).

2 Strnad v. Strnad, 190 Misc. 768, 78 N.Y.S.2d 390, 391-92 (Sup. Ct. 1948).

339 Misc. 2d 1083, 242 N.Y.S.2d 406 (Sup. Ct. 1963). The Gursky court disapproved the conclusion reached by the Strnad court.

${ }^{4} 68 \mathrm{Cal} .2 \mathrm{~d}$ 280, 437 P.2d 495, 66 Cal. Rptr. 7 (1968). See also, Smith, Artificial Insemination-No Longer a Quagmire, 3 FAM. L.Q. 1 (1969); Smith, For Unto Us a Chite Is Born-Legally!, 56 A.B.A.J. 143 (1970).
} 
proceeded to hold that a husband who gives his consent to his wife's use of AID intervention, cannot disclaim his lawful fatherhood of the child for the purpose of child support. The court construed a state penal nonsupport statute to incorporate liability of a consenting father of the AID child, finding a genetic relationship, as such, unnecessary in order to establish the required father-child relationship. ${ }^{5}$

A greater degree of sophistication was shown by the New York Supreme Court in 1973 with its decision in Adoption of Anonymous. ${ }^{6}$ Instead of according blind precedential value to Gursky, the court found a strong state policy favoring legitimacy and, further, that a child born of consensual artificial insemination by a donor, accomplished as such during a valid marriage, is legitimate and thus entitled to enjoy all rights and privileges of a child who is conceived in a natural way by the same marriage.

Since the Sorensen and Anonymous decisions, several states have passed legislation legitimizing the offspring of AID when the husband consents to the procedure. ${ }^{7}$ These judicial and legislative developments indicate clearly that both branches of government no longer equate AID with adultery and may even signal the public's willingness to sanction more startling genetic developments. ${ }^{8}$

Interestingly, a 1969 Harris opinion survey of some 1600 adults throughout the country relative to advances and applications of the "new" biology, revealed a most intriguing attitudinal profile. Nineteen per cent of all interviewed approved of AID, while $56 \%$ disapproved of the process. Where the only method for a married

\footnotetext{
${ }^{5} 68$ Cal. 2d 280, 437 P.2d 495, 66 Cal. Rptr. 7 (1968). See generally, J. GoldsteIN, A. Freud, \& A. Solnit, Beyond the Best Interest of THE Child (1973). ${ }^{6} 74$ Misc. 2d 99, 345 N.Y.S.2d 430 (Sup. Ct. 1973).

'See, e.g., Alaska Stat. \& 20.20.010 (1975); ARK. Stat. AnN. \$ 61-141(c) (1971); CaL. Civ. Code $\$ 7005$ (West 1975); Colo. Rev. Stat. \$ 19-6-106 (1977); ConN. Gen. Stat. $\$$ 45-69(f) (1975); Fla. STAT. ANN. \$ 742.11 (West 1973); KAN. STAT. \$ 23-219 (1977); LA. Civ. Code AnN. art. 188 (West 1975); Md. Est. \& Trusts Code AnN. $\$ 1-206$ (b) (1975); Mont, Rev. Codes ANN $\$$ 61-306 (1975); N.Y. DoM. Rel. LAW $\$ 75$ (McKinney 1974); N.C. Gen. STat. § 49A-1 (1974); Okla. Stat. tit. 10, 552 (1974); OR. Rev. Stat. $\$$ 109.243 (1977); TeX. FAM. Code ANN. tit. 2, § 12.03 (Vemon 1977); VA. Code $\$ 64.1-7.1$ (1977); WASH. REV. CODE ANN. \$26.26.050(1) (1976); Wyo. STAT. \& 14-2-103(a) (1978). ' Smith, The Medicolegal Challenge of Preparing for a Brave Yet Somewhat Frightening New World, 5 J. Legal MEd. 9 (1977). See also, Smith, Manipulating the Genetic Code: Jurisprudential Conundrums, 64 GEo. L.J. 697 (1976); Smith, Through a Test Tube Darkly: Artificial Insemination and the Law, 67 MICH L. REV. 127 (1968); Shaman, Legal Aspects of Artificial Insemination, 18 J. FAM. L. 331 (1980).
} 
couple to conceive a family involved use of heterologous insemination (AID), 35\% of those interviewed approved of the technique. Forty-nine per cent of the men interviewed in the survey agreed in principle with homologous insemination (AIH)-semen taken from the putative husband-while $62 \%$ of the women expressed their approval of allowing their husband's semen to be used through artificial means of injection, in order to inseminate them. ${ }^{9}$

\section{FITZGERALD v. RUECKL}

A case pending presently before the Nevada Supreme Court where it has been set for argument in 1981, holds particular interest for students of the law and science of artificial insemination. ${ }^{10}$

As might be expected, the facts of the situation which support and give rise to the subsequent legal action, are disputed by each party. What is conclusive, however, is that Michael P. Fitzgerald and his former wife, Rulanda, have maintained individual actions against Dr. Frank V. Rueckl seeking money damages stemming from acts of artificial insemination performed in 1972 by Dr. Rueckl on Rulanda Fitzgerald. Mr. Fitzgerald claimed the physician had an obligation to obtain his written consent before inseminating his wife; that he should not be held responsible for any of the child's subsequent medical bills, which originally totaled over $\$ 40,000.00$ and have presently been reduced to $\$ 15,000.00$; and, that he and his former wife should be awarded damages for the psychological strain on them individually and in the context of their marriage stemming from the circumstances of her pregnancy and the baby's condition.

The plaintiff, Michael Fitzgerald, divorced his wife Diane, the mother of his five children, in 1969. Before the divorce, however, the plaintiff began living with his future wife, Rulanda. A healthy son, also Michael, was born in March, 1967, of Rulanda.

${ }^{9}$ Smith, For Unto Us a Child Is Born, supra note 4.

${ }^{10}$ Fitzgerald v. Rueckl, supra note 1 . The discussion of this case devolves from the various pleadings submitted before the Second Judicial District Court of Nevada, Washoe County, filed October 20,23, 1978. Copies of these, together with Appellants' and Appellee's briefs to the Supreme Court of Nevada are on file in the office of The Journot of Legal Medicine. A telephone conversation with Gary C. Backus, Esq., Counsel for the Plaintiffs, November 14, 1978, from Washington, D.C., also provided pertinent information and insight into the case. 
Two years after his divorce was finalized, the plaintiff married Rulanda on February 3, 1971. Prior to the validation of his second marriage, Mr. Fitzgerald had a vasectomy. Thereafter, following their marriage, the plaintiffs decided to seek medical advice relative to the possibilities of reversing the vasectomy. Advised that such surgery was quite painful and carried no real chance for success, the plaintiffs sought other alternatives to help realize their joint wish to have additional children. Adoption was rejected by both. Thereupon, contact was made with a physician in Oakland, California, where the plaintiffs then resided and discussion was undertaken relative to the feasibility of AID. The risks to Ms. Fitzgerald and the possible psychological consequences to her husband were all discussed carefully. The Oakland physician, Dr. Bassett, started an ovulation chart with the patient and her temperature was taken every morning in order to determine when she was ovulating and, accordingly, when she would be disposed to a successful AID intervention.

In the meantime, Mr. Fitzgerald moved to Reno, Nevada. Having ascertained that his wife wished to go ahead with the procedure, the local Planned Parenthood Organization was contacted. It was learned from this organization that Dr. Frank Rueckl was the only physician in Reno who was performing artificial insemination.

According to the defendant's pleadings, Dr. Rueckl was thereupon contacted. He advised Mr. Fitzgerald of a number of considerations which should appropriately be addressed before AID could be administered. Mr. Fitzgerald explained that he was already fully cognizant of all the matters connected with the entire procedure and he requested that Dr. Rueckl proceed. Thereupon, Mr. Fitzgerald and his wife prepared a family background record and the wife executed a written consent form. Interestingly, Nevada has no law requiring consent of a husband in matters of this nature or, for that matter, any laws regarding artificial insemination. Ms. Fitzgerald made three separate monthly appointments with Dr. Rueckl for the purpose of being artificially inseminated.

Two months into the pregnancy, Mr. Fitzgerald communicated to Dr. Rueckl his inability to accept the present condition of his wife. Because of religious beliefs, a therapeutic abortion was not considered to be a feasible alternative. About a month later, Mr. Fitzgerald became abusive and forced his wife to leave their home and return to California where she was able to live with a 
relative. Later correspondence and a spirit of reconciliation fostered by Mr. Fitzgerald, brought his wife back to Reno. Before the birth of the child, Mr. Fitzgerald acknowledged the child to be as his own. After the child was born, however, he again became abusive with his wife and new son.

In June, 1974, the plaintiffs separated. The infant was healthy until the approximate age of three months. At that time, he "failed to thrive" and was treated at the medical centers of Stanford University and the University of California in San Francisco. At no time during the treatment was it determined that the child's condition was the result of the actual AID intervention. Before the age of two, the child died. No autopsy was performed and no specific cause of death was established. The plaintiffs divorced following the death of the child. Surprisingly, the divorce decree contained no provision relative to the fatherhood of either the first child born of Rulanda and Michael's relationship out of wedlock nor the second one conceived artificially within the state of matrimony. At issue, thus, is the extent of legal liability on the part of Mr. Fitzgerald for any "necessaries" provided to the children, particularly the medical services provided to the second son during his life.

The District Court Judge, James Guinan, ruled at trial that the husband's written consent was an unnecessary prerequisite to the wife's artificial insemination despite the fact that an objective reading of the facts would appear to give rise to an implied consent on the part of Mr. Fitzgerald regarding the AID. Judge Guinan further ruled that the doctor's right to refuse disclosure of the identity of the sperm donor would be upheld and that Mr. Fitzgerald was not responsible for the medical bills incurred in keeping the child alive for nearly two years.

The pertinent Nevada statute relative to consent is significant. It states that consent of a patient for a medical or surgical procedure is obtained if the patient is told in general terms, without specific detail, the procedures to be undertaken, the nature of alternative methods of treatment, if any, and a disclosure of the risks which may exist, together with the general nature and extent of the risks involved, although without specific enumeration of the risks being set out. Finally, the patient's signature is to be obtained on a statement containing an explanation of the procedure, alterna- 
tive methods of treatment and risks involved as provided by the statute. ${ }^{\text {! }}$ ?

Persuasive authority exists, however, for the proposition that the consent of a married woman in full possession of her faculties is sufficient to authorize performance of medical or surgical treatment on her without any consent on the part of her husband. ${ }^{12}$ Nor, for that matter, need a physician even notify the husband of the possible effects of treatment which, according to the accepted standards of the profession, is deemed necessary for administration to the wife. ${ }^{13}$ Given the clearly enunciated importance of women's rights in our society, as well as the woman's specific right of self determination or autonomy over her own body, the issue of a husband's consent being necessary for an act to be performed upon his wife's body has become less significant. ${ }^{14}$ Yet, even without regard for the spousal consent question, since Dr. Rueckl apparently never advised Rulanda Fitzgerald that a child born of an artificial impregnation might be born with a genetic defect, one extended theory of plaintiff's case for development on appeal is whether, as to Ms. Fitzgerald, a truly informed consent was given.

\section{A. Informed Consent}

At the January, 1979, meeting of the American Association for the Advancement of Science in Houston, Texas, Dr. J.K. Sherman, Professor of Anatomy at the University of Arkansas School for Medical Sciences and a leader in designing national and international standards for human semen cryobanking, noted that of the

11 Nev. Rev. Stat. § 41A.110 (1973).

12 Rosenberg v. Feigin, 119 Cal. App. 2d 783, 260 P.2d 143; Annot., 79 A.L.R.2d 1028, 1034 (1953); Annot., 99 A.L.R.2d 1336, 1388 (1953). See Murray v. Vandevander, 522 P.2d 302 (Okla. 1974); 61 AM. Jur. 2d, Physician \& Surgeon § 161 (1972).

1338 CAL. JUR. 2d 672 (1957).

${ }^{14}$ In New York, it is provided by statute that a written consent must be executed by a married woman seeking to be artificially inseminated and by her husband if the issue therefrom is to be considered legitimate. N.Y. DoM. REL. LAW $\$ 73$ (McKinney 1977). See also, CAL. Civ. Code $\$ 7005$ (West 1975).

is footnote deleted.

16 footnote deleted.

${ }^{17}$ footnote deleted.

18 footnote deleted.

19 footnote deleted. 
normal population, a seven per cent rate of defective newborn is to be found, while of the studies made of those women who conceived artificially, through AID using frozen semen, less than one per cent of the issue born were genetically defective. ${ }^{20}$ The question thus becomes whether the statistical probability of genetic error occurring was so significant that Dr. Rueckl should have advised Ms. Fitzgerald of the chance of something going wrong in her use of AID.

The parameters of the doctrine of Informed Consent are so fluid and flexible, particularly in situations such as these, that the lengths to which a physician must go in order to obtain a truly informed consent from a patient are "ill defined at best." 21 While some authorities would argue that it is vitally important to include virtually all known complications and risks, others note convincingly that in order to obtain a legally binding informed consent, only revelation of significant risk is necessitated. ${ }^{22}$ Thus, employing a rule of reason approach to the conundrum, the average ordinary "reasonable" physician should be guided by the basic realization that if there is, indeed, a high (statistical) risk of danger associated with a medical intervention of whatever kind, that risk should be explained fully to the patient and, in turn, the informed consent obtained. ${ }^{23}$

\section{B. Negligence}

In addition to informed consent, another theory of recovery sought by the plaintiffs sounds especially in negligence or, medical malpractice, on the part of Dr. Rueckl in performing the act of artificial insemination. While this cause of action appears reasonable on its face, it will nevertheless be extremely difficult for the plaintiffs to show that the birth defects were proximately caused by the physician's errors in the process of administering artificial insemination. ${ }^{24}$ There appears to be little substantial evidence of

${ }^{20}$ See generally National Academy of Sciences, The Integrity of Frozen SperMATOZOA (1978).

21 Alfidi, Controversy, Alternatives, and Decisions in Complying with the Legal Doctrine of Informed Consent, in Contemporary Issues in Bioethics 146, 147 (T. Beauchamp, \&

L. Walters, eds. 1978).

${ }^{22}$ Id. See generally Ch. 4 of CONTEMPoRARY IsSUES in BIOETHICS.

${ }^{23} \mathrm{Id}$. at $148,149$.

${ }^{24}$ See Huffman v. S.S. Mary \& Elizabeth Hosp., 475 S.W.2d 631 (1972). 
any causal connection between the conduct of Dr. Rueckl and the medical condition of Ms. Fitzgerald's deceased child, since to establish a causal connection here, a reasonable probability not a mere possibility must be shown. ${ }^{25}$ Yet, negligence on the part of Dr. Rueckl in selecting the donor may well be an act which creates legal liability.

The opinion of the New York Court of Appeals in the consolidated case of Becker v. Schwartz and Park v. Chessin, ${ }^{26}$ may serve as a pertinent influence or vector of force for the Nevada High Court in grappling with Fitzgerald $v$. Rueckl. There the Court held that where a physician fails to apprise a married couple with a given genetic deficiency (profile) of the risks of bearing a handicapped child and neglects to advise of availability of tests for detecting the disorder, and a defective child is subsequently born, the physician, under basic malpractice law, is liable to the parents for the special costs of raising the handicapped child. It would thus appear that an expansive, yet rational reading of this holding could lead the Nevada Supreme Court to conclude that Dr. Rueckl is guilty of malpractice for failing to work up a full and careful genetic profile of the donor and his compatability with the co-plaintiff wife and, for failing to disclose all relevant information to the wife in order to enable her to give an informed consent to the AID procedure.

\section{Strict Liability}

Another rather intriguing theory for recovery by the plaintiffs is tied to the doctrine of strict liability; the argument being that the goods (e.g., the donor's semen) were defective and thus, the doctor breached the warranty of fitness which all goods must carry with them. Admittedly, this is a rather fanciful case theory. In some jurisdictions, especially California, the law is settled that a doctor diagnosing and treating a patient is normally not selling either a product or insurance. In order for the doctrine of strict liability to be applicable, one must find that the seller-here, Dr.

\footnotetext{
${ }^{25}$ Spencer v. Beatty Safeway Scaffold Co., 141 Cal. App. 2d 875, 297 P.2d 746 (1956).

${ }^{26} 46$ N.Y.2d 401, 413 N.Y.S.2d 895 (1978). See Curlender v. Bio-Science Labs., 100 Cal. App. 3d 811 (1980) (where the California Court of Appeals allowed a genetically defective child to sue in her own capacity under a theory of wrongful life to recover damages for pain and suffering during her limited life span and any spceial pecuniary loss resulting from the impaired condition). See generally Capron, Tort Liability in Genetic Counseling, 79 Colum. L. ReV. 618 (1979).
} 
Rueckl-was engaged in the business of selling such a product. ${ }^{27}$ To be remembered is the fact that Dr. Rueckl was a general practitioner and not a sperm bank director or entrepreneur. Yet, drawing upon a growing number of decisions which hold that since defective blood is inherently dangerous and its seller is to be held strictly liable for harm caused therefrom, ${ }^{28}$ a court could rule that genetically defective semen was akin to defective blood and thus impose liability for its improper use. Indeed, in donor semen cases, certain contaminants and genetic diseases can be detected easily, whereas in life saving emergency conditions, the purity of donor blood is more difficult to guarantee. Because of the inherent discrepancies in the two cases, a court could well indeed be more willing to impose strict liability for errors in administering artificial insemination. ${ }^{29}$

Cases have held that where the primary objective is to obtain professional services, strict liability and warranty do not apply. The patient's main objective is to achieve pregnancy-not to purchase semen.$^{30} \mathrm{~A}$ physician, then, utilizes artificial insemination in order to assist his patient in becoming pregnant and the use of semen to achieve that result is but incidental to the central object sought to be accomplished. Therefore, the process of artificial insemination is arguably but a classic physician service, as is furnishing blood to a patient, and is not subject to the doctrines of warranty or strict liability. ${ }^{31}$

\section{Donor Confidentiality v. The Right To Know}

Although the identity of the donor in the instant Fitzgerald case was not revealed in the lower court, he was acknowledged to be a medical student. Dr. Rueckl further acknowledged that he

${ }^{27}$ Carmichael v. Reitz, 17 Cal. App. 3d 958, 979, 95 Cal.2d 846 (1975); Perlmutter v. Beth David Hosp., 308 N.Y. 100, 123 N.E.2d 792 (1954).

${ }^{28}$ Bell Bonfils Mem. Blood Bank v. Hansen, 579 P.2d 1158 (Colo. 1978); McDonald Blood Bank, 62 Cal. App. 3d 866, 133 Cal. Rptr. 444 (1976); Steinck v. Doctor's Hosp. 82 Misc. 2d 97, 368 N.Y.S. 2d 767 (Sup. Ct. 1975).

${ }^{29}$ See Frankel, Artificial Insemination and Semen Cryobanking: Health and Safety Concerns and the Role of Professional Standords, Law and Public Policy, 3 Legal Med Q. 93 (1979).

${ }^{30}$ See Link-Belt Co. v. Star Iron \& Steel Co., 65 Cal. App. 3d 24, 135 Cal. Rptr. 134, 142 (1976) See also Note Products and the Professional. Strict Liability in the Sales-Service 
spent only a few minutes talking to the donor, thus leading to the plaintiffs' assertion that the doctor was guilty of malpractice in failing to properly screen the donor and ascertain his genetic profile and compatability with Ms. Fitzgerald. The plaintiffs presume that there was a mismatch between the donor and Rulanda Fitzgerald and contend, further, that "no admissible evidence points to anything other than an inherited defect [from the donor]."

There is a rather alarming precedent being set within the field of adoption law that has serious possibilities of jeopardizing, through broad construction, donor secrecy in AID cases. District of Columbia Superior Court Judge Green recently ruled that a twenty-two-year-old mother of two children, living in Takoma Park, Maryland, who was herself adopted as a child, should be granted permission to see her sealed birth records and thus learn the identities of her natural parents. ${ }^{32}$ The plaintiff in this case asserted her basic right to know her total historical identity, and to discover whether hereditary diseases or other health problems were a part of her genetic inheritance. ${ }^{33}$

A similar argument along the same lines could obviously be made by the progeny of AID. The argument for disclosure would gain even more persuasiveness in light of recent findings in the New England Journal of Medicine. ${ }^{34}$ Statistics from a recent study showed that sperm from one donor had in fact been used to produce fifty children and thus raised the very real danger of accidental incest among offspring who unknowingly have the same father. ${ }^{35}$ The article also recorded the sloppiness of some doctors in failing to screen genetically the donors who participate in AID procedures. A mere twenty-nine percent of physicians tested the donors of semen, and of those who did test, evaluation was primarily for communicable diseases. Most recipients were inseminated twice per cycle. Only seventeen percent of the physicians used the

${ }^{32}$ Whitaker,Birth Data Ruled Open to Adoptee, Wash. Post, Feb. 5, 1979, at C1, col. 5. The tormented and disastrous quest of an adopted girl to learn the identity of her actual parents is vividly portrayed in fiction in P.D. JAMES, INNOCENT BLOOD (1980). See generally Wadlington, Artificial Insemination: The Danger of a Poorly Kept Secret, 64 N.W.U.L. REV. 777 (1970).

${ }^{33}$ Whitaker, supra note 32.

${ }^{34}$ Currie-Cohen, Luttrell \& Shapiro, Current Practice of Artificial Insemination by Donor in the U.S. 300 New England J. Med. 585 (1979).

${ }^{35} \mathrm{Id}$. at 587 . 
same donor for a given recipient, and thirty-two percent used multiple donors within a single cycle. Only thirty-seven percent kept records on children, and only thirty percent kept records on donors. The identity of donors usually was carefully guarded to ensure privacy and to avoid legal complications. ${ }^{36}$

Of seven hundred eleven physicians likely to perform AID who were surveyed to determine their current practices, four hundred seventy-one responded, of whom three hundred seventy-nine reported that they performed this procedure. They accounted for approximately three thousand five hundred seventy-six births by this means in 1977. In addition to treating infertility; twenty-six percent of these physicians used the procedure to prevent transmission of a genetic disease, and ten percent used it for single women. Donors of semen were primarily from universities. They were only superficially screened for genetic diseases and were then matched phenotypically to the recipient's husband. ${ }^{37}$

In Fitzgerald, the obvious reason for discovery of the donor's identity is the imposition of financial liability for the progeny that were fathered. A less obvious reason is a determination of whether Dr. Rueckl took all necessary genetic and other medical precautions in selecting the donor.

Provisions within the Uniform Parentage Act $^{38}$ provide that all records involving AID interventions are to be kept "confidential and in a sealed file." Inspection of them is only sanctioned when a court order acknowledges the existence of "good cause." Although, on balance, Fitzgerald $v$. Rueckl presents inadequate cause for breaching AID confidentiality, from a mere evidentiary basis with no reference to the Uniform Parentage Act, the day may soon be here where a stronger case arises and disclosure of donor identity may be necessary.

As observed, by drawing upon analogous right-to-know-

${ }^{36} I d$.

${ }^{37}$ Id.

${ }^{3 B}$ The following states have adopted, in essence, these provisions of Section 5 of The Uniform Act: Cal. Civ. Code \& 7005(a) (West 1975); Colo. Rev. STAT. § 19-6-106(I) (1977); Conn. Gen. Stat. \& 45-69(h) (1975); Kan. Stat. \$ 23-130 (1977); Mont. Rev, Codes AnN. \$ 61-306 (1975); N.Y. City Health Code \$ 21.07 (1959); OkLa. Stat. tit. $10, \S 553$ (1974); OR. ReV. Stat. § 677.365(3) (1977); WASH. REV. CodE ANN $\$ 26.26 .050$ (1976); Wyo STAT. § 14-2-103(a) (1978). See Note, The Uniform Parentage Act: What It Will Mean for the Putative Father in California, 28 Hastings L.J. 191 (1976). 
parental-identity cases arising in regular adoption areas, "good cause" in order to discern the identity of a donor in artificial insemination cases could be determined to exist not only for reasons of obtaining complete medical information regarding the child's donor "father,' but for reasons of allowing the AID child to resolve questions of identity, promote social adjustment, establish a bond of love ${ }^{39}$ promote a wish to be of genuine assistance and support to a biological family unit ${ }^{40}$ and to determine if the rules of intestate succession are applicable. ${ }^{41}$

The right to know parental lineage has also received recent federal attention. Efforts were undertaken by Senator Carl Levin of Michigan in the second session of the 96th Congress to amend The Child Abuse Prevention and Treatment and Adoption Reform Act of 1978 to provide for a national computerized adoption identification center. This proposed legislation is entitled The Adoption Identification Act of 1980.42 The specific purpose of the legislation is "to provide a system whereby the natural parents, siblings, or other natural relatives of an adoptee can locate each other through a centralized computer system." 43 The Center, to be established within the former Department of Health, Education and Welfare, will be tied to voluntary participation by all involved parties. State participation through the development of state computer centers is provided. ${ }^{44}$

In essence, a natural parent, a sibling or other natural relative or offspring submits an application to a computerized adoption identification center and thereby initiates the locating process. The application is then programmed into the national or state computer in an effort to match the parent, the offspring, the sibling or the other relative. All subjects who fit the profile of the data which are submitted are in turn printed out and made available to the particu-

${ }^{39}$ In re Adoption of Female Infant, 5 FAM. L. REP. 2311 (1979); In re Adoption of Spinks, 32 N.C. App. 422, 232 S.E.2d 479 (1977).

${ }^{40}$ In re Ann Carol S., 172 N.Y.L.J. 31, Aug. 13, 1974, at 12, col. 6.

${ }^{41}$ Spillman v. Parker, 332 So.2d 573 (La. Ct. App. 1976). See Annas, Artificial Insemination: Beyond the Best Interests of the Donor, 9 HASTings CENTER ReP. 14 (1979); Smith, Artificial Insemination: Disclosure Issues, 11 Colum. Human Rights L. Rev. 87 (1979).

${ }^{42}$ S. 2561 . It was referred to the Senate Committee on Labor and Human Resources and the Subcommittee on Child and Human Development. See also 126 Congressional Record: S. 3660 (April 15, 1980).

${ }^{43}$ Sec. 301.

${ }^{44}$ Sec. 304. 
lar agency which becomes involved with the follow-up procedure. Provision is made for additional research and actual interviewing for purposes of conclusively determining whether the subjects match. Storage for computer information of this nature is guaranteed for ten years. If no successful match is made within this time frame, application may be made to apply for a renewal of the application, itself, for another ten-year period.

On April 2, 1980, Senate Resolution 401 was introduced by Senator John Tower expressing disapproval of the proposed legislation which would,

require either automatic opening at the request of an adult adoptee of confidential birth records, court records, and adoption agency records and require agencies to notify adult adoptees that a birth parent desires to meet the adoptee even if the adoptee had not expressed a desire to meet with his birth parents. ${ }^{45}$

Senator Levin, in proposing this legislation, was careful to state that it would allow adoptees and birth parents to communicate only where there exists mutual interest in communicating; thus any intrusion into the life of either party or any prospective violation of constitutional privacy rights would be avoided. No action of any nature could be taken by the Center unless and until both the adoptee and his or her natural parent(s), siblings or other natural relatives have independently made contact with the Center. ${ }^{46}$

III. C.M. v. C.C.

The State of New Jersey was the jurisdictional setting for the second case of topical concern and precedential value. ${ }^{47}$ Here, C.C., an unmarried woman, conceived a child through sperm artificially donated by a long-time friend of some two years, C.M. C.C. had considered artificial conception with other friends, but C.M. suggested that he be the one to assist since he and C.C. had in fact often spoken of eventual marriage. For some unreported reason, C.C. did not want to have normal intercourse with C.M. before they married. Thereupon the parties consulted a doctor who

\footnotetext{
${ }^{45} \mathrm{~S}$. Res. 401.

${ }^{46} 126$ Congressional Record, supra note 42. This proposed legislation died in the Subcommittee on Child and Human Development. With very slight modification, it will be reintroduced during the first Session of the 97th Congress.

${ }^{47}$ C.M. v. C.C., 152 N.J. Super. 160, 377 A.2d 821 (1977).
} 
in turn referred them to a sperm bank. While refusing the couple's wish to use the facilities of the sperm bank, the doctor in charge revealed to C.C. the procedures used for achieving artificial insemination: a glass syringe and a glass jar.

Regular visits were made by C.C. to C.M.'s apartment for the express purpose of artificially inseminating C.C. There was no carnal connection in the strict legal sense. Rather, C.M. stayed in one room and when he had completed producing semen, C.C. would be called and she, in turn, would come from a separate room, obtain the semen and return to a private room in the apartment where she would proceed to inseminate herself artificially. After a number of attempts, success was achieved and conception occurred. No cohabitation followed.

Until about the third month of pregnancy, C.M. assumed he would be allowed to act toward the subsequent issue, when born, in the same manner as any other father might act toward a natural child he had sired. C.C. testified that during this period of the pregnancy, C.M. was but a visitor in her private home from time to time as other friends were. The "relationship" between C.C. and C.M. subsequently ended.

When the child was born, C.M. sought visitation rights and it was this application which formed the basis of the case before the court. The central issue thus became whether C.M. was the natural father of the child and thus entitled to visitation rights, as well as subject to the tenancy of the child and the payment of expenses incurred during birth; or, in the alternative, whether C.M. was not the natural father because the sperm used to conceive the issue was transferred to C.C. by unnatural, artificial means. ${ }^{48}$

The court, while refusing to take a specific position on the propriety of the use of artificial insemination between unmarried persons, nonetheless ruled that public policy demanded that, whenever possible, it was in the best interests of a child to have two parents. Accordingly, the court held that as to custodial and visitation rights, no distinction should be made between a child conceived naturally and artificially. C.M.'s petition was granted. The court, in recognizing C.M. as the natural father, also recognized and imposed upon him the responsibility to support and maintain the child. Contrary to C.C.'s argument that C.M. was

${ }^{48}$ Id. at 822 . 
"unfit," the court found him to be educationally and financially able to meet the responsibilities and obligations of parenthood as a member of the teaching profession and concluded that he had a genuine interest in the child.

Although not finding an exact case on point for precedential guidance, the court did look to and draw from certain related cases in order to guide it in resolving the dilemma of the instant case. Even as to an illegitimate child, it has been established that a natural father is entitled to exercise rights of visitation. ${ }^{49}$ In the instant case, the court rightly determined with relative ease that despite the artificiality and "strained uniqueness" of conception, C.M. was in fact the natural father of the issue born of C.C.'s use of his sperm.

Not only are the best interests of a child served, but also the best interests of society are served in preventing or, at best, easing the pressures and taint of illegitimacy by determinations such as those made by this capable New Jersey judiciary. While the initial social, ethical and religious concerns relative to the procedure engaged in by C.C. and C.M. cannot be ignored, the immediate welfare of a guiltless child and the economic costs imposed upon society in raising that child must be considered paramount and, indeed, controlling. Finding legitimacy in cases of this nature is the only equitable solution. By no means should such a finding be taken as a legal, social, ethical, or religious condonation of the act of artificial insemination by unmarried couples. Rather, such a recognition of the primacy of legitimacy as the real, over-riding issue here is but a humane and enlightened legal response to an admittedly troublesome problem.

The basic reason for allowing a married couple to give birth to a child by artificial insemination, namely, the expression and fulfillment of their love through procreation, does not apply when an unmarried woman, who cannot assure her child a normal, traditional family relationship, seeks the use of artificial insemination. It was obviously because of this social and even ethical prohibition, that the physician in charge of the sperm bank refused to allow C.C. to use the services of the sperm bank. Yet, the liberalization of certain state adoption laws that now permit single individuals to

${ }^{49}$ R. v. F., 113 N.J. Super. 396, 273 A.2d 808 (City Ct. 1971). 
adopt children ${ }^{50}$ and the growing recognition of the liberation of women, present perhaps growing doubts relative to the validity of the rationale of such a societal constraint. ${ }^{51}$

\section{CONCLUSION}

As the courts begin to recognize " a best interests of the child test,' in deciding vexatious cases involving artificial insemination, it would surely appear that where genetic heritage is brought into question concerning the health and well-being of an AID child, the confidential files (if such are maintained) of a physician participating in AID intervention, should be examined by a judge in camera and, where necessary, with the assistance of a geneticist. Public disclosure of the donor's identity should not be revealed ${ }^{52}$ nor, for that matter, should liability be imposed upon him for "errors" that might follow as a consequence of his participation. As has been asserted, it is the doctor who must be looked to for error.

Perhaps the New York Court of Appeals has signaled, with its decision in Becker v. Schwartz and Park v. Chessin ${ }^{53}$ that the court will impose upon physicians a high standard of care and medical foresight and will thus seek to effect this purpose by tightening the decisional law of malpractice. A physician who is negligent in failing to properly screen prospective donors for artificial insemination must bear the consequences of his errors.

Greater safeguards must be undertaken in order to preserve the integrity of artificial insemination as a medico-legal process. If physicians are not sufficiently careful in their supervision and administration of the AID process, then the states must act in order to guarantee higher standards of professional care. In addition to judicial activism, legislative implementation should be sought by creating presumptions at law of the legitimacy of issue born of consensual AID, thus clarifying both the legal rights and duties of the husband. To the extent that greater confidentiality of donor

\footnotetext{
${ }^{50}$ See N.Y. Dom. Rel. LAw § 110 (McKinney 1977); 2 AM. Jur. 2d Adoption § 10 (1963).

${ }^{51}$ See Smith, Uncertainties on the Spiral Staircase: Meta-ethics and the New Biology, 41 Pharos 10 (1978); Comment, Contracts to Bear a Child, 66 CAL. L. Rev. 611 (1978).

52 P. Reilly, Genetics, Law and Social Policy 202 (1977). See generally J. Waltz \& F. Inbau, Medical Jurisprudence, Ch. 4 (1971); 1, 2 D. Louisell, \& H. Williams, Medical Malpractice (1977).

5346 N.Y.2d 401, 413 N.Y.S.2d 895 (1978).
} 
records would be strengthened, additional adoptions of the Uniform Parentage Act should be advocated.

While the New Jersey Court in C.M. v. C.C. ${ }^{54}$ dramatically showed itself to be concerned with protecting the interests of the child born of an artificial union while at the same time protecting the best interests of the social and economic order which favors legitimization, the Supreme Court of Nevada has, in "Fitzgerald $v$. Rueckl, a unique opportunity to both reaffirm and guarantee these basic value considerations.

${ }^{54} 152$ N.J. Super. 160, 377 A.2d 821 (1977). 